УДК 355.58.001; 351.862.11

\title{
ОГЛЯД ЦИВІЛЬНОГО ЗАХИСТУ: НОРМАТИВНО-ПРАВОВА БАЗА, ШЛЯХИ РЕАЛІЗАЦІЇ ТА КІНЦЕВІ РЕЗУЛЬТАТИ
}

\author{
https://doi.org/10.33269/nvcz.2021.2.92-100
}

\author{
Слюсар A. A. ${ }^{1}$,ORCID iD 0000-0002-3492-32092 \\ Калиненко Л. B ${ }^{1^{*}}$.,ORCID iD 0000-0002-2507-4183 \\ Фомін A. I. ${ }^{1}$, ORCID iD 0000-0003-0754-1750 \\ Запольський Л. Л. ${ }^{1}$ ORCID iD. 0000-0003-4357-2933 \\ Ільїна H. Є. ${ }^{1}$ ORCID iD 0000-0002-5455-8566 \\ Морщ Є. B. ${ }^{2}$ ORCID iD 0000-0003-0131-2332 \\ *E-mail : 1kalynenko@gmail.com \\ ${ }^{1}$ /нститут державного управління та наукових досліджень з цивільного захисту, Україна \\ ${ }^{2}$ Департамент запобігання надзвичайним ситуаціям Державної служби України з надзвичайних \\ cumуаціŭ
}

\section{ІНФОРМАЦІЯ ПРО СТАТТЮ}

Надійшла до редакції: 01.10.2021

Пройшла рецензування: 08.12.2021

КЛЮЧОВІ СЛОВА:

огляд цивільного захисту, оцінювання спроможностей, базові елементи (складові) спроможностей, функціональні групи (інтегровані категорії) спроможностей, каталог спроможностей, планування на основі спроможностей короткострокове, середньострокове, довгострокове.

\begin{abstract}
АНОТАЦІЯ
Огляд цивільного захисту - це комплекс заходів, що проводиться 3 метою визначення стану готовності єдиної державної системи цивільного захисту, її функціональних і територіальних підсистем, сил цивільного захисту до реагування на можливі надзвичайні ситуації, стану захищеності населення та територій від таких ситуацій. Ключовими у цьому процесі $€$ аналіз і оцінювання спроможностей сил та засобів цивільного захисту щодо виконання покладених завдань і на цій основі планування розвитку єдиної державної системи цивільного захисту та її складових, що є новим напрямом, який тільки започатковується у цій сфері.

У статті викладено коментарі до вимог чинних нормативноправових актів. Охарактеризовано мету та завдання огляду цивільного захисту на основі спроможностей, методи і порядок його проведення, кінцеві результати та їх використання для розроблення Стратегії громадської безпеки та цивільного захисту України. Інформація, наведена у статті, призначена для фахівців, що провадять свою діяльність у сорері цивільного захисту.
\end{abstract}

Постановка проблеми. Згідно із Законом України «Про національну безпеку України» основним документом довгострокового планування, в якому визначено найважливіші напрями державної політики у сфері національної безпеки, підгрунтям для підготовки всіх інших нормативно-правових актів щодо планування у сферах національної безпеки і оборони є Стратегія національної безпеки України (далі - Стратегія нацбезпеки) [1].

На засадах Стратегії нацбезпеки за результатами огляду громадської безпеки та цивільного захисту розробляється Стратегія громадської безпеки та цивільного захисту України - документ довгострокового планування, в якому окреслено напрями державної політики щодо гарантування захищеності життєво важливих для держави, суспільства та особи інтересів, прав і свобод людини i громадянина, цілі та очікувані результати їх досягнення 3 урахуванням актуальних загроз.

Складовою частиною огляду цивільного захисту України $є$ огляд спроможностей 
функціональних та територіальних підсистем єдиної державної системи цивільного захисту (далі - СДСЦЗ).

\section{Аналіз останніх досліджень}

і публікацій. За результатами опрацювання низки законодавчих i нормативно-правових документів щодо цивільного захисту та національної безпеки й оборони, статей щодо оборонного стратегічного планування на основі спроможностей стосовно Збройних сил України, деяких зарубіжних документів, у тому числі НАТО [1-19], автори дійшли висновку, що оцінювання наявних, необхідних, надлишкових спроможностей та планування на їх підгрунті в Україні було засновано у сфері оборони 3 урахуванням підходів, прийнятих у державах-членах НАТО, і розвивається впродовж останніх років досить інтенсивно. Разом із тим у сфері безпеки, зокрема у сфері цивільного захисту, ці поняття є новими, а запроваджуватися почали 3 моменту започаткування роботи зі створення Стратегії громадської безпеки та цивільного захисту України.

Актуальність

дослідження підтверджується існуванням запиту щодо методології і методики проведення огляду й оцінювання спроможностей та планування розвитку цивільного захисту на цій основі, визначення учасників цього процесу, процедури й порядку його проведення, використання результатів цієї діяльності для формування Єдиного каталогу спроможностей цивільного захисту. На сьогодні зазначених вище методологій i методик немає, але роботи в цьому напрямі проводяться, зокрема в Інституті державного управління та наукових досліджень 3 цивільного захисту (далі ІДУ НД ЦЗ), - завершується виконання науково-дослідної роботи «Спроможності Ц3».

Методи дослідження. Використано метод теоретичних досліджень, складовими якого $є$ такі операції, як аналіз, синтез, аналогія, порівняння, узагальнення, систематизація тощо.
Виклад основного матеріалу. Нормативна база 3 питань огляду цивільного захисту та планування на основі оцінки спроможностей невелика, отже, необхідно докласти значних зусиль для ii розширення.

Основним нормативним актом 3 цього питання є Закон України «Про національну безпеку України» [1], у якому визначено, що сили цивільного захисту входять до складу сектору безпеки і оборони (п. 16) і є силами безпеки (п. 17). Крім того, у ньому започатковано проведення комплексного огляду сектору безпеки і оборони (п. 8).

$\mathrm{He}$ менш важливим документом $\epsilon$ постанова Кабінету Міністрів України «Про затвердження Порядку проведення огляду громадської безпеки та цивільного захисту Міністерством внутрішніх справ» [2]. У цьому Порядку встановлено організаційні, методичні засади підготовки i проведення МBC огляду стану захищеності інтересів людини й громадянина, суспільства і держави від суспільно небезпечних діянь, негативного впливу криміногенної ситуації та стану захисту населення i територій від надзвичайних ситуацій. Огляд містить дві складові: перша - це огляд громадської безпеки, друга - цивільного захисту.

Огляд цивільного захисту (далі - огляд Ц3) - це процедура оцінювання стану готовності єдиної державної системи цивільного захисту, iï функціональних та територіальних підсистем, сил цивільного захисту до реагування на можливі надзвичайні ситуації та стану захищеності населення і територій від таких ситуацій.

Відповідно до постанови [2] визначено поетапне проведення огляду ЦЗ. Зокрема, на його основному (виконавчому) етапі мають бути здійснені аналіз та оцінка спроможностей функціональних та територіальних підсистем єдиної державної системи цивільного захисту, сил цивільного захисту щодо ефективності та оперативності реагування на прогнозовані надзвичайні ситуації, наслідки військових конфліктів, а також здатності оперативно розв'язувати завдання за призначенням як 
основоположні серед усього комплексу призначених для огляду заходів.

Визначення та огляд спроможностей цивільного захисту (далі - ВОСЦЗ) - це процес, який здійснюється:

по-перше - періодично і обов'язково під час огляду цивільного захисту як складової частини комплексного огляду сектору безпеки і оборони, що проводиться за рішенням Ради національної безпеки i оборони України відповідно до Указу Президента України;

по-друге - в інтервалах між проведенням комплексних оглядів сектору безпеки i оборони керівником суб'єкта забезпечення цивільного захисту може бути ухвалено рішення про проведення цільових оглядів (у разі необхідності).

Мета таких оглядів - проведення аналізу відповідності окремих спроможностей, функціональних груп спроможностей та спроможностей територіальних i функціональних підсистем загалом, їх оцінювання відповідно до сценаріїв реагування на можливі надзвичайні ситуації та вироблення обгрунтованих рекомендацій для формування узгоджених, реалістичних i прийнятних рішень (матеріальних та нематеріальних) 3 розвитку відповідних спроможностей, структури і складу складових ЄДСЦЗ 3 урахуванням стану безпекового середовища та встановлених ресурсних обмежень.

Типовими проблемами за результатами проведення ВОСЦЗ можуть бути:

- неможливість досягти в нинішніх умовах необхідних спроможностей (потребує матеріальних рішень);

- кількісні та якісні показники спроможності недостатні (потребує матеріальних та нематеріальних рішень);

- закінчення життєвого циклу носіїв спроможності (потребує матеріальних рішень).

Залежно від мети огляду в процедурі ВОСЦЗ передбачається порівняння наявних спроможностей з тими, що мають бути у їх носія відповідно до вимог нормативно-правових актів, настанов, статутів, стандартів, інструкцій, табелів, засад (основ, принципів) застосування, стандартних операційних процедур (алгоритмів) та інших керівних документів, а також зі спроможностями, що можуть знадобитись у перспективі, за результатами прогнозування.

Крім того, згідно з процедурою ВОСЦЗ передбачається виявлення недоліків у вимогах до спроможностей, встановлення нових чи оновлення сучасних вимог.

Під час ВОСЦЗ за необхідності розробляються рекомендації щодо проведення певних змін одночасно в усіх споріднених організаційних структурах, носіях відповідних спроможностей.

Головною метою ВОСЦЗ є перевірка наявності найкращих спроможностей у межах виділених бюджетних видатків у функціональних та територіальних підсистемах ЄДСЦЗ, їх силах і засобах загалом, або їх окремих складових.

Під час огляду встановлюється:

- відповідність спроможностей критеріям ефективності їх оперативного застосування, необхідним для успішного виконання завдань;

- брак (нестача) або надлишок необхідної кількості аварійно-рятувальної, пожежної та спеціальної техніки, аварійнорятувального та пожежного обладнання й оснащення, запасів матеріально-технічних засобів для забезпечення цих спроможностей та пов'язані 3 ними оперативні ризики;

- можливий нематеріальний підхід для пом'якшення або усунення дефіциту спроможностей, а в разі необхідності ухвалення матеріальних рішень (щодо протипожежної, аварійно-рятувальної та іншої спеціальної техніки, обладнання, механізмів, приладів, інструментів тощо).

Для організації та проведення ВОСЦЗ послуговуються чинними національніими стандартами, методиками та керівництвами, регламентами, положеннями та інструкціями, а також можуть бути використані як вітчизняні, так i міжнародні практики, описані у відповідних стандартах та публікаціях НАТО [12-13] і Збройних сил України 
[9-11], якщо вони не суперечать законодавству України.

Відповідно до визначеної мети ВОСЦЗ поділяється на типи залежно від цілей огляду:

- розв'язання проблем та усунення недоліків у наявних спроможностях;

- оцінювання готовності до врегулювання прогнозованих потреб на перспективу (в тому числі з урахуванням невиконаних програм (планів)) тощо;

- в інтересах забезпечення виконання необхідних дій щодо реагування на можливі в майбутньому масштабні $\mathrm{HC}$;

- перевірки перспективних планів 3 оперативного застосування сил, матеріально-технічного, медичного забезпечення, застосування наявних чи перспективних зразків техніки та оснащення тощо;

- поглибленого вивчення окремої спроможності, групи спроможностей чи функціональної групи спроможностей;

- розроблення рекомендацій щодо вирішення найбільш проблемних питань, що стосуються окремої спроможності чи групи спроможностей.

Об'єктом огляду в ЄДСЦЗ є окрема спроможність, група спроможностей чи функціональна група, які визначені у функціональних групах спроможностей ЄДСЦЗ та стосовно яких проводиться ВОСЦЗ. Суб'єктами огляду є робоча група, створена для проведення ВОСЦЗ, чи окремий призначений суб'єктом представник забезпечення ЦЗ.

ВОСЦЗ передбачає проведення таких основних процедур, як оцінювання безпеки середовища (на конкретній територіi), визначення та оцінювання спроможностей органів управління та сил ЦЗ, визначення потреби в ресурсах, оцінювання ризиків, удосконалення нинішньої структури ЄДСЦЗ та іiі складових або формування нової (до аварійно-рятувального формування включно), підготовка підсумкового документа за результатом ВОСЦЗ. Цей процес схематично наведений на рис. 1.

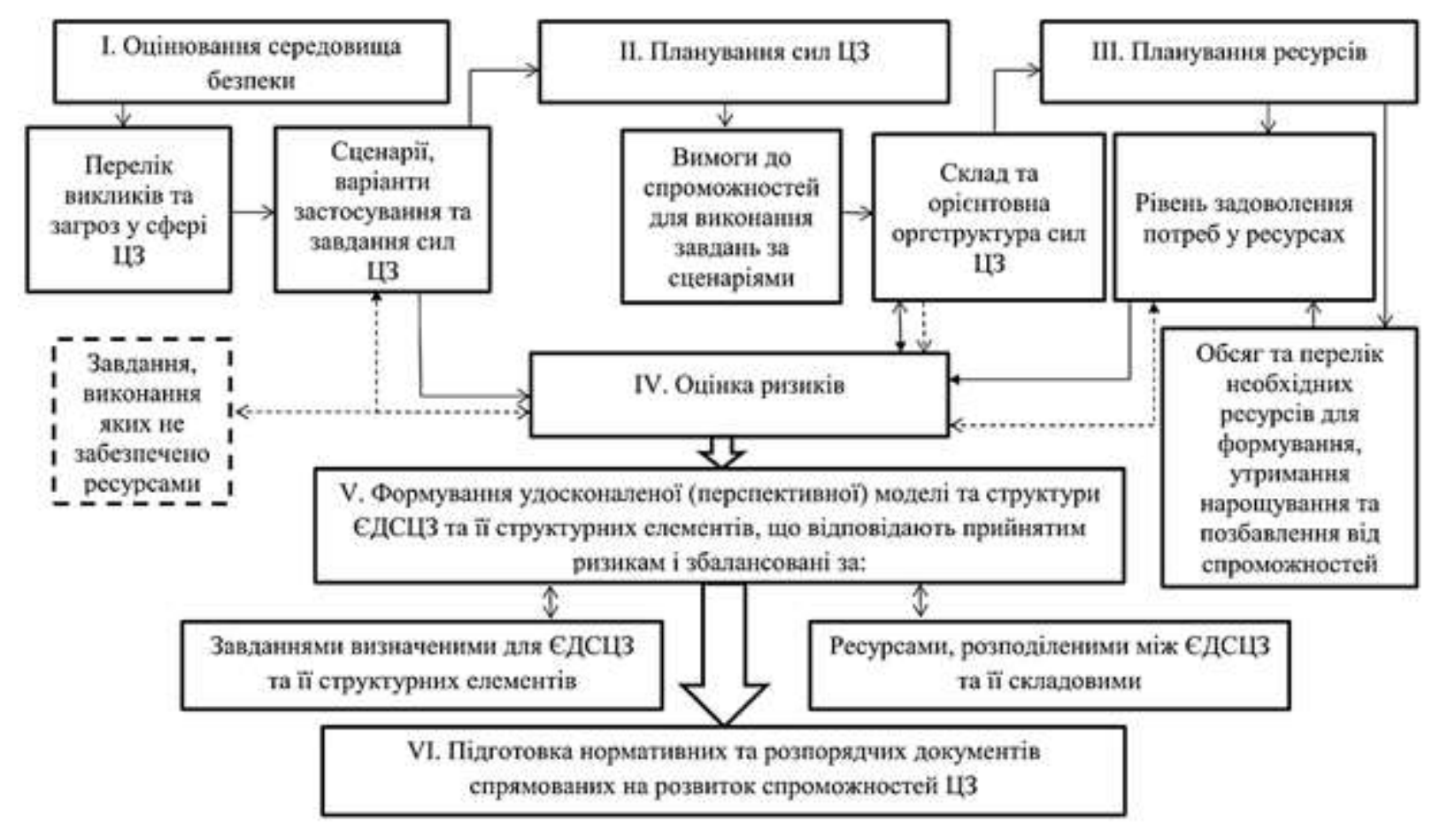

Рисунок 1 - Перелік та взаємний зв'язок між процедурами проведення ВОСЦЗ

Джерело: розроблено авторами 
Під час процедури оцінювання середовища безпеки визначається перелік викликів та загроз у сфері цивільного захисту, аналізуються перспективи їх розвитку на окремій території та України загалом, формуються на їх основі ймовірні сценарії реагування на $\mathrm{HC}$, за яких застосовуються сили та засоби СДСЦЗ та їі складових.

У межах цієї процедури з'ясовується ймовірність виникнення тих чи інших сценаріїв НC, визначаються завдання органам управління та силам ЦЗ за кожним сценарієм i варіанти їх застосування, а також вимоги до спроможностей (на державному, регіональному, місцевому та об'єктовому рівнях) щодо виконання завдань за всіма сценаріями.

Між проведенням ВОСЦЗ здійснюється моніторинг середовища безпеки та за необхідності вносяться зміни до ймовірних сценаріїв i варіантів застосування сил та засобів ЄДСЦЗ та іiі складових.

Враховуючи характеристики викликів та загроз у сфері цивільного захисту України, пріоритети політики держави у цій сфері, аналізується широкий спектр імовірних ситуацій та варіантів їх розвитку, до яких можуть застосовуватись (залучаються) сили та засоби ЄДСЦЗ. Ці ситуації об'єднуються відповідними сценаріями.

Водночас враховуються вимоги положень Стратегії національної безпеки України, Стратегії громадської безпеки та цивільного захисту України, відповідні акти Президента України, Кабінету Міністрів України, зокрема постанови «Про затвердження Порядку проведення огляду громадської безпеки та цивільного захисту Міністерством внутрішніх справ» [2], інших нормативно-правових актів та нормативних документів у сфері цивільного захисту.

Визначення та оцінювання спроможностей органів управління та сил ЦЗ здійснюється на основі варіантів застосування сил та засобів ЄДСЦЗ та ii складових для виконання завдань, визначених у сценаріях. Воно включає:

$$
\text { встановлення необхідних }
$$

спроможностей для виконання завдань за сценаріями та варіантами застосування;

- оцінювання наявних спроможностей та їх відповідності чинним вимогам (здатності до виконання завдань за призначенням);

- визначення недостатніх i надлишкових спроможностей шляхом порівняння необхідних та наявних спроможностей;

- планування заходів 3 утримання наявних, формування недостатніх та позбавлення від надлишкових спроможностей.

Відповідно до вказаного підходу передбачається:

- визначення завдань за кожним із сценаріїв та рівнем небезпечної події, які в подальшому мають бути зведені в об'єднаний перелік типових завдань функціональної групи (підгрупи);

- опис умов та критеріїв виконання завдань (умов ӥ виконання): оперативних, технічних, спеціальних тощо, які у сукупності складають вимоги до спроможностей, для формування каталогів спроможностей функціональних груп та підгруп 3 подальшим включенням їх до Єдиного переліку (каталогу) спроможностей цивільного захисту;

- підбір 3 Єдиного каталогу спроможностей Ц3 (каталогів спроможностей функціональних груп та підгруп) спроможностей, які відповідають визначеним завданням;

- визначення пріоритетних із обраних спроможностей (критичних, необхідних, наявних, надлишкових) відповідно до завдань 3 урахуванням перспективи їх розвитку;

- формування цільового пакета необхідних спроможностей та відповідного їм складу сил.

За підсумком ВОСЦЗ формуються висновки (оцінка) щодо відповідності, перевищення чи нестачі спроможностей об’єкта оцінювання та пропозиції щодо 
матеріальних та нематеріальних управлінських рішень (підтримання наявних спроможностей, нарощування (удосконалення) базових компонентів (складових) спроможностей, формування нових чи позбавлення від надлишкових спроможностей).

Для ухвалення раціонального рішення щодо вибору (розвитку) спроможностей 3 метою виконання необхідних завдань та визначення пріоритетності їх досягнення можуть застосовуватись різні апробовані та доступні методи та методики, зокрема метод багатокритеріального аналізу, де показники визначаються методом експертних оцінок (метод Делфі) [20], інші розрахункові задачі, спеціальне програмне забезпечення.

Зведення необхідних спроможностей (з урахуванням ïx рейтингів) у єдиний каталог дає змогу сформувати цільовий пакет спроможностей, необхідних для виконання завдань на відповідному рівні державного управління, за певним сценарієм та визначити необхідний склад сил.

Висновки та напрями подальшого дослідження. 3 метою забезпечення ефективної реалізації державної політики у сфері цивільного захисту, яку здійснюють ЄДСЦЗ та ii складові шляхом запровадження нових підходів до оцінювання стану цивільного захисту згідно із законодавством України, запроваджено визначення та огляд (аналіз) спроможностей цивільного захисту, за результатами якого (у подальшому) має здійснюватись планування розвитку цивільного захисту на основі спроможностей з урахуванням підходів та процедур, прийнятих в інших організаціях, що входять до складу сектору безпеки та оборони, а також у державах-членах НАТО.

Автори за результатами проведеного у 2020 році огляду реагування на надзвичайні ситуації, наслідки військового конфлікту на сході, здатності оперативно розв'язувати завдання за призначенням функціональними та територіальними підсистемами єдиної державної системи цивільного захисту визначили особливості спроможностей у сфері цивільного захисту, дослідили основні властивості (вимоги до них) спроможностей та їх носіїв.

Встановлено, що бракує аналізу конкретних методів та механізмів підтримки процесів упровадження запропонованих підходів у діяльність ДСНС, що, на наш погляд, має бути предметом подальших досліджень i розробок.

Уперше систематизовано за функціональним призначенням та науково обгрунтувано основні базові компоненти та функціональні групи спроможностей єдиної державної системи цивільного захисту.

Уперше розроблено шляхи, форми й методи визначення спроможностей та на основі цього розроблено проєкт Рекомендацій 3 огляду спроможностей функціональних i територіальних підсистем єдиної державної системи цивільного захисту та проєкт структури Єдиного каталогу цивільного захисту, що в перспективі має забезпечити проведення оцінювання спроможностей ЦЗ як елементу планування на основі спроможностей, 3 урахуванням підходів, прийнятих $\mathrm{y}$ державах-членах НАTO, a також формування в ЄДСЦЗ, органах управління, установах, організаціях спільного розуміння щодо підходів до впровадження такого планування та порядку його здійснення.

Наявність глибокого аналізу та оцінювання всіх складових оперативних спроможностей i базових компонентів організаційних структур дає змогу більш виважено оцінювати необхідні ресурси для забезпечення розвитку ЦЗ, ретельніше підходити до розроблення стратегій розвитку спроможностей, ухвалювати інвестиційні рішення, управління пакетом спроможностей та розвитку сил ЦЗ.

Втілення в практику планування на основі спроможностей ЦЗ процедур оцінювання та аналізу складових оперативних і спеціальних спроможностей, базових компонентів спроможностей 
можна вважати одним iз напрямів ii адаптації до принципів та правил, що використовують країни - члени НАТО. У подальшому доцільно внести зміни до сучасного процесу планування у сфері цивільного захисту, додавши до нього процедури оцінювання складових оперативних спроможностей та аналізу їх базових компонентів.

\section{СПИСОК ВИКОРИСТАНИХ ДЖЕРЕЛ}

1. Про національну безпеку України : Закон України від 21.06.2018 p. № 2469-VIII. URL : https://zakon.rada.gov.ua/laws/card/2469-19 (дата звернення : 01.10.2021).

2. Про затвердження Порядку проведення огляду громадської безпеки та цивільного захисту Міністерством внутрішніх справ : постанова Кабінету Міністрів України від 22.05.2019 р. № 507. URL : https://zakon.rada.gov.ua/laws/show/507-2019$\% \mathrm{D} 0 \% \mathrm{BF}$ Техт (дата звернення : 01.10.2021).

3. Кодекс цивільного захисту України : Закон України від 02.10.2012 р. № 5403-VI. URL : https://zakon.rada.gov.ua/laws/card/5403-17 (дата звернення : 01.10.2021).

4. Про рішення Ради національної безпеки і оборони України від 6 травня 2015 року «Про Стратегію національної безпеки України : Указ Президента України від 26.05.2015 p. № 287. URL : https://zakon.rada.gov.ua/laws/card/287/2015 (дата звернення : 01.10.2021).

5. Про рішення Ради національної безпеки і оборони України від 4 березня 2016 року «Про Концепцію розвитку сектору безпеки i оборони України : Указ Президента України від 14.03.2016 p. № 92. URL : https://www.president.gov.ua/documents/922016-19832 (дата звернення : 01.10.2021).

6. Про організацію планування в секторі безпеки і оборони України : Указ Президента України від 16.05.2019 p. № 225. URL : https://www.president.gov.ua/documents/2252019-26835 (дата звернення : 01.10.2021).

7. Про затвердження Порядку класифікації надзвичайних ситуацій техногенного та природного характеру за їх рівнями : постанова Кабінету Міністрів України від 24.03.2004 p. № 368. URL : https://zakon.rada.gov.ua/laws/card/368-2004-\%D0\%BF (дата звернення : 01.10.2021).

8. Про організацію оборонного планування в Міністерстві оборони України і Збройних Силах України у 2018 році на 2019 2021 роки : наказ Міністерства оборони України від 19.12.2017 p. № 670. URL : https://ips.ligazakon.net/document/view/MUS 29792?an=1 (дата звернення : 01.10.2021).

9. Рекомендації з оборонного планування на основі спроможностей в Міністерстві оборони України та Збройних Силах України. Міністерство оборони України : вебсайт. Київ, $2017 . \quad$ URL https://www.mil.gov.ua/content/other/Recommendationson CBP 120617.pdf (дата звернення : 01.10.2021).

10. Оборонний огляд : український вимір 2014-2018 : монографія / Ф. Саганюк та ін..; за заг. ред. І. Руснака. Київ : МО та ГШ ЗС України, НУОУ, 2019. 196 с.

11. Henry C. Bartlett, G. Paul Holman, Jr. and Timothy E. Somes. The Art of Strategy and Force Planning. Strategy and Force Planning. 4 th edition. Newport, R. I. : Naval War College Press, 2004. P. 17-33.

12. Handbook on Long Term Defence Planning, RTO Technical Report 69. Paris : NATO Research and Technology Organization, April 2003. URL : http://www.rta.nato.int/pubs/rdp.asp? RDP=RTO-TR-069 (last accessed : 01.10.2021).

13. AAP-03 Ed. J Ver. 3, Production, maintenance and management of NATO standardization documents. URL : https://cutt.ly/PUq8v23 (last accessed : 01.10.2021).

14. Guide to Capability-Based Planning, TR-JSA-TP3-2-2004. The Technical Cooperation Program, Joint Systems and Analysis Group, Technical Panel 3, MORS Workshop, October 2004.

15. Todor Tagarev. The Art of Shaping Defense Policy : Scope, Components, Relationships (but no Algorithms) Connections. The Quarterly Journal 5. № 1 (Spring-Summer 2006). P. 15-34. URL : https:// consortium.pims (last accessed : 01.10.2021).

16. Поліщук В. Б., Нетесін І. С., Нестеренко О. В. Інформаційні технології в управлінні оборонними ресурсами: методологічний контекст та приклади практичної реалізації : монографія / за ред. В. Б. Поліщука. Ч. 1 /. Київ : УкрНЦ РІТ, 2019. $120 \mathrm{c}$.

17. Калинеко Л. В., Слюсар А. А, Фомін А. І., Борисова А. І. Спроможності у сфері цивільного захисту. Науковий вісник : Цивільний захист та пожежна безпека. Т. 1. № 1 (2020). С. 4-13.

18. Дєнєжкін М. М.. Вплив оцінювання та аналізу спроможностей на визначеннязаходів розвитку Збройних сил України. Збірник наукових праиь Харківського начіонального університету Повітряних Сил. 2018. Вип. 3(57). С. 57-63.

19.Дєнєжкін М. М., Крикун П М., Руснак І. С. Проблеми проведення комплексного огляду сектора безпеки та оборони України, погляди на його організацію та вирішення завдань. Наука і оборона. 2014. № 4(7). C. 3-10. URL : http://www.irbisnbuv.gov.ua/cgi-bin/irbis_nbuv/cgiirbis_64.exe?I21DBN=LINK\&P21DBN=UJ (дата звернення : 06.12.2021).

20. The Delphi Method : Techniques and Applications - Harold A. Linstone and Murray Turoff (Eds.). 1975. URL : https://web.njit.edu/ turoff/pubs/delphibook/ch1.html. (last accessed : 01.10.2021). 


\section{REFERENCES}

1. Pro natsionalnu bezpeku Ukrainy [On the national security of Ukraine]: Zakon Ukrainy vid 21.06.2018 № 2469-VIII. Retrived from https://zakon.rada.gov.ua/laws/card/2469-19 [in Ukrainian].

2. Pro zayverdzhennia Poriadku provedennia ogliadu gromadtskoi bezpeky ta tsyvilnogo zahystu [On approval of the Procedure for conducting a review of public safety and civil protection] : postanova KM Ukrainy vid 22.05.2019. № 5/data zvernennia 01.10.2021). Retrieved from https://zakon.rada.gov.ua/laws/show/507-2019-\%D0\%BF\#Text [in Ukrainian].

3. Kodeks tsyvilnogo zahystu Ukrainy [Code of Civil Protection of Ukraine type dated 02.10.2012 № 5403-VI] vid від 02.10.2012 № 5403-VI. Retrieved from https://zakon.rada.gov.ua/laws/card/5403-17 [in Ukrainian].

4. Pro rishennia Rady natsionalnoi bezpeky I oborony Ukrainy vid 06/05.2015 «Pro Strategiu natsionalnoibezpeku Ukrainy» [On the National Security Strategy of Ukraine] vid 26.05.2015 № 287/2015// Baza danykh «Zakonodavstvo Ukrainy» / Verkhovna Rada Ukrainy. Retrieved from https://zakon.rada.gov.ua/laws/card/287/2015 [in Ukrainian].

5. Rishennia Rady natsionalnoi bezpeky i oborony Ukrainy vid 04.03.2016 «Pro Kontseptsiu rozvytku sektora bezpeky i oborony Ukrainy» [On the Concept of Development of the Security and Defense Sector of Ukraine]: Ukaz Prezydenta Ukrainy vid 14/03.2016. № 92. Retrieved from https://www.president.gov.ua/documents/922016-19832[in Ukrainian].

6. Pro organizatsiu planuvannia v sektori bezpeky $\mathrm{i}$ oborony Ukrainy [On the organization of planning in the security and defense sector of Ukraine] vid 16.05.2019. № 225. Retrieved from https://www.president.gov.ua/documents/2252019-26835[in Ukrainian].

7. Pro zatverdzhennia Poriadku klasyfikatsii nadzvychainuh sytuatsii tehnogennogo ta pryrodnogo harakteru za ih rivniamy [About the statement of the Order of classification of emergency situations of technogenic and natural character on their levels] : Pos tanova KM Ukrainy vid 24.03.2004. № 368. Retrieved from https://zakon.rada.gov.ua/laws/card/368-2004-\%D0\%BF//[in Ukrainian].

8. Pro organizatsiu oboronnogo planuvannia v ministerstvi oborony Ukrainy I Zbroinyh syl Ukrainy u 2018 rotsii на 2019-2021 roky [On the organization of defense planning in the Ministry of Defense of Ukraine and the Armed Forces of Ukraine in 2018 for 2019 2021] : Nakaz Ministersyva oborony Ukrainy vid 19.12. 2017 N 670. Retrieved from https://ips.ligazakon.net/document/view/MUS 29792?an=1[in Ukrainian].

9. Rekomendatsii z oboronnogo planuvannia na osnovi spromozhnostei v Ministerstvi oborony Ukrainy ta zbroynyh sylah Ukrainy [Capacity-based defense planning recommendations in the Ministry of Defense of Ukraine and the Armed Forces of Ukraine] / $\begin{array}{llllll}\text { Ministerstvo } & \text { oborony } & \text { Ukrainy. } & \text { Kuiv. } & 2017 . & \text { Retrieved }\end{array}$ https://www.mil.gov.ua/content/other/Recommendationson_CBP_120617.pdf [in Ukrainian].

10. Oboronnyi ogliad ukrainskyi vymir 2014-2018 (2019) : monografia [Defense Review: Ukrainian Dimension 2014-2018: monograph] / F. Saganiuk, A. Pavlikovskyi, P. Shchypanskyi ta insh..; za red. d. viisk. nauk, prof. I. Rusnaka. Kyiv : MO ta GSH ZS Ukrainy, NUOU. 196 s. [in Ukrainian].

11. Henry C. Bartlett, G. Paul Holman, Jr., and Timothy E. Somes (2004). The Art of Strategy and Force Planning, in Strategy and Force Planning. 4th edition. Newport, R.I. : Naval War College Press, 2004. P. 17-33 [in English].

12 Handbook on Long Term Defence Planning, RTO Technical Report 69.Paris : NATO Research and Technology Organization (2003). Retrieved from https://www.rta.nato.int/pubs/rdp.asp? RDP=RTO-TR-069 [in English].

13. AAP-03 Ed. J Ver. 3, Production, maintenance and management of NATO standardization documents. Retrieved from https://cutt.ly/1Uq8B6M [in English].

14. Guide to Capability-Based Planning, TR-JSA-TP3-2-2004. The Technical Cooperation Program, Joint Systems and Analysis Group, Technical Panel 3, MORS Workshop, October 2004 [in English].

15. Todor Tagarev. The Art of Shaping Defense Policy: Scope, Components, Relationships (but no Algorithms), Connections. The Quarterly Journal 5. no. 1 (Spring - Summer 2006). P. 15-34. URL : https:// consortium.pims [in English].

16. Polishchuk V. B., Netesin I. Ie., Nesterenko O. V. (2019) Informatsiini tekhnolohii v upravlinni oboronnymy resursamy: metodolohichnyi kontekst ta pryklady praktychnoi realizatsii : monohrafiia. [Information technologies are in a management defensive resources: methodological context and examples of practical realization] Kyiv UkrNTs RIT. [in Ukrainian].

17. L. Kalynenko, A. Slusar, A. Fomin and Borysova (2020). Spromozhnosti u sferi tsyvilnogo zahystu [capability of civil protection] K. Naukovyi visnyk: Tsyvilnyi zahyst ta pozhezhna bezprka [in Ukrainian].

18. M. Denezhkin (2014). Vplyv otsiniuvannia ta analizu spromozhnostei na vyznachennia zahodiv rozvytku Zbroinyh syl Ukrainy [Influence of evaluation and analysis of possibilities is on determination of measures of development of Military powers of Ukraine] Kharkiv/ Zbirnyk naukovyh prats Kharkivskogo natsionalnogo Universytetu Povitrianyh syl. [In Ukrainian].

19. M. Denezhkin, P. Krykun.and I. Rusnak. (2014) Problemy provedennia kompleksnogo ogliadu sektora bezpeky ta oborony [Problems of leadthrough of complex review of sector of safety and defensive of Ukraine, looks to his organization and decision of tasks]. Nauka iI oborona [in Ukrainian].

20. The Delphi Method : Techniques and Applications - Harold A. Linstone and Murray Turoff (Eds.). (1975). URL : https://web.njit.edu/ turoff/pubs/delphibook/ch1.html [in English]. 


\title{
CIVIL PROTECTION REVIEW: REGULATORY LEGAL ACTS, WAYS OF IMPLEMENTATION AND FINAL RESULTS
}

\author{
A. Sliusar ${ }^{1}$, L. Kalynenko ${ }^{1}$, A. Fomin ${ }^{1}$, L. Zapolskiy', N. Ilina ${ }^{1}$, Ye. Morshch ${ }^{2}$ \\ ${ }^{1}$ Institute of Public Administration and Research in Civil Protection, Ukraine \\ ${ }^{2}$ Department of Emergency Prevention of the State Emergency Service of Ukraine
}

\begin{tabular}{|c|c|}
\hline EYWORDS & ANNOTATION \\
\hline $\begin{array}{l}\text { civil protection } \\
\text { review, capacity } \\
\text { assessment, basic } \\
\text { elements } \\
\text { (components) of } \\
\text { capabilities, } \\
\text { functional groups } \\
\text { (integrated } \\
\text { categories) of } \\
\text { capabilities, } \\
\text { capacity catalog, } \\
\text { capacity-based } \\
\text { planning. }\end{array}$ & $\begin{array}{l}\text { The Civil Defense Review is a set of measures taken to determine the state of readiness } \\
\text { of the unified state civil defense system, its functional and territorial subsystems, civil } \\
\text { defense forces to respond to possible emergencies and the state of protection of the } \\
\text { population and territories from such situations. The key in this process is the analysis and } \\
\text { evaluation of the capabilities of civil defense forces and means to perform the assigned } \\
\text { tasks and on this basis to plan the development of a single state civil protection system } \\
\text { and its components, which is a new direction in this area. } \\
\text { The article comments on the requirements of current regulations, describes the purpose } \\
\text { and objectives of the review of civil protection on the basis of capabilities, methods and } \\
\text { procedures, its final results and their use to develop a strategy for public safety and civil } \\
\text { protection of Ukraine. } \\
\text { Having in-depth analysis and evaluation of all components of operational capabilities and } \\
\text { basic components of organizational structures allows more balanced assessment of } \\
\text { resources needed to ensure the development of the Central Command, more careful } \\
\text { approach to developing capacity development strategies, investment decisions, capacity } \\
\text { management and development of the Central Command. } \\
\text { The implementation of capability-based planning procedures for assessing and analyzing } \\
\text { the components of operational and special capabilities, the basic components of } \\
\text { capabilities can be considered one of the ways to adapt it to the principles and rules used } \\
\text { by NATO member countries. }\end{array}$ \\
\hline
\end{tabular}

